\title{
Implications of Labour welfare measures on Job Satisfaction and productivity: A Study Of Cotton Textile Industry in Punjab \\ Minakshi Garg ${ }^{1}$, Dr. Pardeep Jain ${ }^{2}$ \\ ${ }^{1}$ Research Scholar, Deptt. of Management, SLIET Longowal, Distt Sangrur Punjab ${ }^{1}$ minakshi garg100@rediffmail.com(91-9815000157) \\ ${ }^{2}$ Professor, Deptt. of Management, SLIET Longowal, Distt Sangrur Punjab 2 pardeep_jain2000@yahoo.com(91-9463563064)
}

\begin{abstract}
Labour welfare means the effort to make the life comfortable for the workers. Key objective behind providing welfare measures is that workers obtain satisfaction which would ultimately lead to better productivity. Welfare activities will go a long way to better the mental and moral health of workers by reducing vices of industrialization. India which launched a boat of social security sometime in the second half of the nineteen century has still been in troubled waters and is far away from the cherished goal of full social security for her citizens. So this study is conducted to know whether the workers are aware and satisfied with the welfare facilities provided by textile industry in punjab as the textile industry is the single largest manufacturing industry of India which had a strong impact on the development of the labour and trade union movement in India. The study is conducted to make some suggestions for betterment of workers in future because the successful implementation of labour welfare activities are an extension of democratic values in an industrialized society.
\end{abstract}

KEYWORDS: Labour Welfare; Job satisfaction; Awareness; Implementation; Productivity

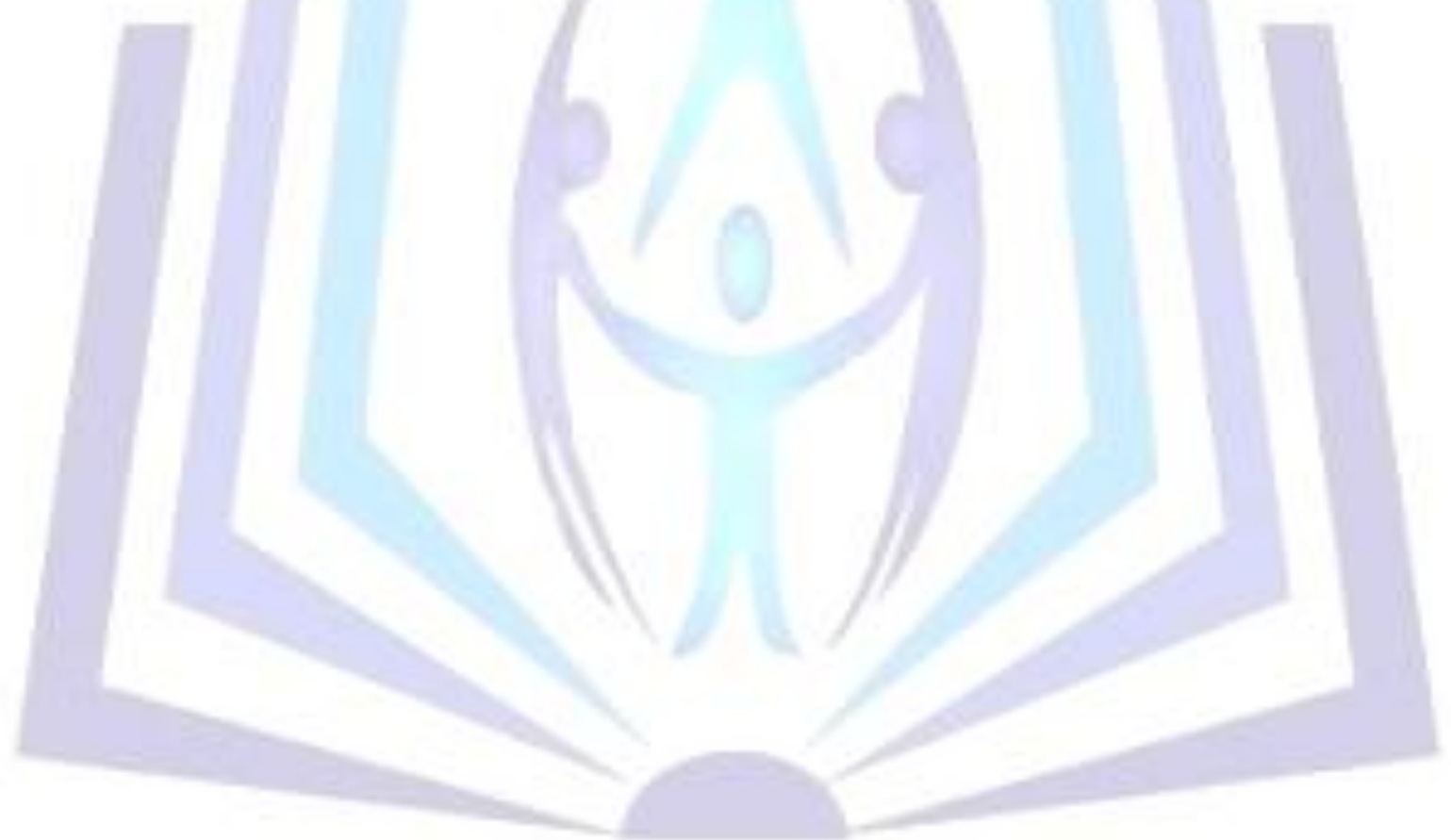

\section{Council for Innovative Research}

Peer Review Research Publishing System

Journal: International Journal of Management \& Information Technology

Vol. 5, No. 2

editor@cirworld.com

www.cirworld.com, member.cirworld.com 


\section{INTRODUCTION}

The industrial workers in India today constitute functionally a very significant vulnerable element of the country's population. They also contribute substantially to the nation's economy. This group faces certain unique problems in their work life like long hours of work in unhealthy surroundings, drudgery of factory work and uncongenial factory environment. Provision of welfare amenities enables the workers to live a richer and more satisfactory life and contributes to the productivity of labour, efficiency of the enterprises and helps in maintaining industrial peace. Adequate levels of earnings, safe and humane conditions of work and access to some minimum security benefits are the major qualitative dimensions of labour welfare which enhance quality of life of workers and their productivity. The significance of welfare measures was accepted as early as 1931, when the Royal commission on labour stated, "The benefits are of great importance to the worker which he is unable to secure by himself. The schemes of labour welfare may be regarded as a wise investment because these would bring a profitable return in the form of greater efficiency. The main aim of welfare measures is partly humanitarian- to enable workers to enjoy a fuller and richer life and partly economic- to improve the efficiency of the workers and also partly civic- to develop among them a sense of responsibility and dignity and thus make them worthy citizens of the nation.

\section{LITERATURE REVIEW}

Setting up of large scale factories in India started from 1850,but this was confined to the textile industry. During this period, workers were unorganized and government also did not pay any attention towards their lot. The first labour unrest at the Empress Mills, Nagpur in 1877 was regarding the improvement of wages. The continued agitation brough about the passing of the Factories Act in 1881. In 1885 the Fatal Accidents act was passed. Inspite of this workers continued to live under inhuman conditions. Before 1920 it was the period of inactivity in social insurance movement in India. But 1920 onwards International Labour Organisation played an important role towards the development of labour welfare. It was perhaps under the banner of ILO that the problem of social security for labour was first discussed. The adoption by ILO of the first social security conventions in the late 1920 gave marked impetus to the world movement in this field. With the dawn of independence, welfare measures for upliftment of labour class were intensified. After independence, the government at a tripartite conference in December 1947 adopted the industrial truce resolution. Several legislations, including the following, were enacted to maintain industrial peace and harmony: Factories Act, 1948, Employees State Insurance Act, 1948 and Minimum Wages Act, 1948. The payment of bonus act was passed in 1965. Kumar P.Ashok (2012) in his study on Labour welfare measures in Salem Steel plant examines the significance and objectives of labour welfare and concluded that labour welfare measures helps to promote industrial relations and to reduce the level of absenteeism. Shobna Mishra and Dr. Manju Bhagat (2010) in their principles for successful implementation of labour welfare activities stated that labour absenteeism in Indian industries can be reduced to a great extent by provision of good housing, health and family case, Canteen, and provision of welfare activities. The principles for successful implementation of labour welfare activities are nothing but an extension of democratic values in an industrialized society. A. Sabarirajan (2010) conducts a study on various welfare measures and their impact on quality of work with reference to Salem District, Tamilnadu, India, he concluded that most of the employees are benefited with the welfare measures provided by mills. He suggested that improvements or modifications are required in the field of recreation facilities, leaves, safety measures, overtime payments, compensatory arrangements on medical grounds, promotion etc. Report on National Commission on labour (2002) Government of India made recommendation in the area of labour welfare measures which include Socia Security, extending the application of the provident fund gratuity and unemployment, insurance etc. K.K. Jacob (2002) study examines industrial relation in public sector in Kerala. Attention has been paid on exploring the nature and extent of industrial disputes, settlement machinery, working conditions and welfare facilities. He concludes that low wages and bonus, poor working conditions and welfare facilities are the most important factor responsible for industrial disputes. A study conducted by Saiyaddin(1983) examined the purpose and cost of non-statutory welfare activities for the organizations. Five public and six private sector organizations were selected for the study. The study brought out an important conclusion that the most predominant theme in the minds of organizations when they think of the voluntary welfare measures was not only the output and efficiency but also increasing loyalty and morale. In respect of cost, the study revealed, that the public sector organizations spend more on welfare activities, as compared to private sector. While public sector spends more on transportation and recreation, private sector was found to be spending more on housing according to the study. Misra(1974) in his research work aimed at sociological analysis of the labour welfare problems of sugar industry. The analysis was based on the first hand data collected from the sugar factories of Eastern Uttar Pradesh. The study concluded that the conditions of work in sugar factories of eastern region of Uttar Pradesh were not very satisfactory particularly in the respect of safety measures, cleanliness, sanitation, latrine facilities, drinking water, rest rooms, etc. It also pointed out that the provisions for leaves and holidays, lighting, housing, medical, education, are far from satisfactory

\section{METHODOLOGY}

The present aim of the study is to analyse the implications of labour Welfare Measures on job satisfaction and productivity. The study has been undertaken in the cotton textile industry in punjab as it is one of the oldest and most firmly established industry. The textile industry provides direct employment to about more than 35 million people and is the second largest employment provider in India after agriculture. Textile industry, the single largest manufacturing industry of India had a strong impact on the development of the labour and trade union movement in India .Industrial relations are not very good in the textile industry in the country. So to evaluate labour welfare measures both statutory and voluntary welfare measures undertaken by the employers are taken into consideration. Data is collected through convenience sampling and population of the study comprises of 250 workers with a gender ratio of 50:50. In this study the schedule 
consist of mostly close ended questions with 5-point Likert Scale i.e Highly Satisfied, Satisfied, Average, Dissatisfied and Highly Dissatisfied. The Statistical tools applied for the study is percentages, weighted average mean and Chi Square. The secondary data is collected with the help of various company records, Company manual, Internet, journal, books etc.

\section{OBJECTIVES OF STUDY}

- To study the level of awareness and satisfaction level for welfare provisions under the Employees State Insurance act, 1948.

- To study the status of the implementation of welfare provisions under the Employees State Insurance act,1948

- To study the status of non-statutory welfare measures and facilities provided to the workers by the cotton textile employers in Punjab.

- To study the level of job satisfaction with respect to welfare provisions provided by the cotton textile employers in Punjab.

- To offer suggestions to improve the standard of Labour welfare measures in cotton textile industry in Punjab

\section{DATA ANALYSIS AND INTERPRETATION}

\section{Level of awareness for Welfare Measures under Employees State Insurance Act, 1948}

In the present study 6 provisions are taken into consideration to know the level of awareness of the workers on each provision. In order to make the interpretation easier, the mean scores are converted into percentage using the formula. Percentage Score $=($ Mean Score -1$) \times 25$. This is done on the assumption that the mean score of 1 indicates 20 per cent, 2 corresponds to 40 per cent, 3 indicates 60 per cent, 4 corresponds to 80 per cent, and lastly 5 indicates 100 per cent. The per cent score indicates the degree to which a particular dimension exists out of the ideal 100.

TABLE I: Level of Awareness For Welfare Measures Under Employees State Insurance Act, 1948

\begin{tabular}{|c|c|c|c|}
\hline S.No. & Provisions/facilities & Weighted Average mean score & Percentage \\
\hline 1 & Sickness benefits & 4.8 & $95 \%$ \\
\hline 2 & Medical benefits & 4.6 & $90 \%$ \\
\hline 3 & Maternity benefits & 4.2 & $80 \%$ \\
\hline 4 & Disablement benefits & 3.6 & $45 \%$ \\
\hline 5 & Dependents benefits & 2.8 & $30 \%$ \\
\hline 6 & Funeral benefits & 2.2 & $35 \%$ \\
\hline
\end{tabular}

Over all Mean Score $=3.7$ Over all Percentage $=67.5 \%$

It can be observed from the above table that the overall mean score of 3.7 i.e. 67.5 per cent indicates that majority of the respondents are aware of the welfare measures provided under the ESI act. From the above table it can be concluded that for sickness and medical benefits, respondents are extremely aware i.e $95 \%$ \& $90 \%$ respectively and for funeral benefits they have very low level of awareness. The level of awareness for maternity benefits and disablement benefits is moderate i.e $80 \%$ and $65 \%$ respectively and are slightly aware of dependents benefits i.e $45 \%$.

Most of the Respondents are not aware of either their rate of monthly contribution towards ESI or management's contribution towards ESI

Table II- Level of Satisfaction With Implementation Of ESI Act, 1948

\begin{tabular}{|c|c|c|c|}
\hline S.No & $\begin{array}{c}\text { SATISFACTION LEVEL FOR WELFARE } \\
\text { FACILITIES UNDER ESI }\end{array}$ & $\begin{array}{c}\text { NO. OF } \\
\text { RESPONDENTS }\end{array}$ & $12 \%$ \\
\hline 1 & Highly Satisfied & 30 & $20 \%$ \\
\hline 2 & Satisfied & 50 & $40 \%$ \\
\hline 3 & Average & 100 & $20 \%$ \\
\hline 4 & Dissatisfied & 20 & $8 \%$ \\
\hline 5 & Highly Dissatisfied & 250 & 100 \\
\hline
\end{tabular}


From the above table it is highlighted that most of the respondents have average level of satisfaction and $30 \%$ of the respondents are on the dissatisfaction side. The problems they face in availing these benefits are that they donot get proper medical facilities like medicines in the ESI hospitals and it is difficult to claim benefits from ESI. So as per their opinion improvements are desirable in the scheme by improving medical service and by simplifying the procedure of getting benefits.

TABLE III--SEX AND LEVEL OF SATISFACTION FOR WELFARE MEASURES UNDER ESI ACT,1948

\begin{tabular}{|c|c|c|c|c|c|c|}
\hline \multirow[t]{2}{*}{ S.No } & \multicolumn{5}{|c|}{ Level Of Satisfaction } & \multirow[b]{2}{*}{ Total } \\
\hline & Highly Satisfied & Satisfied & Average & Dissatisfied & Highly Dissatisfied & \\
\hline Male & $16(53.3 \%)$ & $25(50 \%)$ & $47(47 \%)$ & $26(52 \%)$ & $11(55 \%)$ & 125 \\
\hline Female & $14(46.7 \%)$ & $25(50 \%)$ & $53(53 \%)$ & $24(48 \%)$ & $9(45 \%)$ & 125 \\
\hline & 30 & 50 & 100 & 50 & 20 & 250 \\
\hline
\end{tabular}

Interpretation: It is lime lighted from the above table that the percentage of highly satisfied for welfare measures under ESI in textile industries was the highest (53.3\%) among the Male category of the respondents and the same was the lowest $(46.7 \%)$ among the female category of the respondents. The percentage of average level of satisfaction for welfare measures Under ESI in textile industries was the highest (53\%) among the female category of the respondents and the same was the lowest $(47 \%)$ among the male category of the respondents. Whereas percentage of highly dissatisfied for welfare measures under ESI was the highest (55\%) among the male category of the respondents and the same was the lowest $(45 \%)$ among the female category of the respondents.

In order to find the relationship between sex of the respondents and level of satisfaction for welfare measures under ESI in textile industries, a chi-square test was employed to test the hypothesis and the result of the test is shown in the following table.

Ho: There is no significant relationship between the sex of the respondents and satisfaction level for welfare measures under ESI Act in textile industries.

$\mathrm{H} 1$ : There is a significant relationship between the sex of the respondents and satisfaction level for welfare measures under ESI Act in textile industries.

Table Iv: Sex And Level Of Satisfaction For Welfare Measures Under Esi Act,1948 (Chi-Square Test)

\begin{tabular}{|c|c|c|c|}
\hline & Value & Degree of Freedom & Table value at 5\% Significant \\
\hline Pearson Chi square & 5.37 & 4 & 9.49 \\
\hline
\end{tabular}

Interpretation: It is witnessed from the above table that the calculated chi square value is less than the table value at $5 \%$ significance level. Hence, the null hypothesis $\mathrm{Ho}$ is accepted and alternative hypothesis $\mathrm{H} 1$ is rejected. From the analysis it is concluded that there is no significant relationship between the sex of the respondents and level of satisfaction for welfare measures under ESI.

TABLE V: CLASSIFICATION ON HOUSING ACCOMODATION FACILITY

\begin{tabular}{c|c|c|c|} 
Sr. No. & HOUSING ACCOMODATION FACILITY & NO. OF RESPONDENTS & PERCENTAGE \\
1 & YES & 150 & $60 \%$ \\
2 & NO & 100 & $40 \%$ \\
\hline
\end{tabular}

It is witnessed from the above table that $40 \%$ of the respondents expressed that they are not having housing accommodation and $60 \%$ of the respondents expressed that they are having house accommodation.

TABLE VI : SATISFACTION LEVEL WITH THE FACILITIES IN LABOUR COLONY

\begin{tabular}{|c|c|c|c|}
\hline S.No & $\begin{array}{c}\text { SATISFACTION LEVEL WITH } \\
\text { FACILITIES IN LABOUR COLONY }\end{array}$ & PO. OF RESPONDENTS & $20 \%$ \\
\hline 1 & Highly Satisfied & 30 & $27 \%$ \\
\hline 2 & Satisfied & 45 & $30 \%$ \\
\hline 3 & Average & 25 & $17 \%$ \\
\hline 4 & Dissatisfied & 10 & $6 \%$ \\
\hline & Highly Dissatisfied & 150 & $100 \%$ \\
\hline
\end{tabular}


The above table highlights that most of the respondents are satisfied with the facilities in labour colony. While $17 \%$ are dissatisfied with the facilities in labour colony and they want improvement in the same in terms of timely repair of the houses.

Table Vi: Correlation Between Level of Satisfaction With Implementation of ESI Act And Level of Job Satisfcation

\begin{tabular}{|c|c|c|} 
Variable & Correlation & r/S.E.(r) \\
\hline $\begin{array}{c}\text { Job satisfaction and satisfaction } \\
\text { with implementation of ESI Act }\end{array}$ & 0.4344 & ${\text {. } 2654^{*}}^{*}$ \\
\hline
\end{tabular}

\section{*Statistically significant at Five percent level of satisfaction}

From the above table it is proved that if the workers are highly satisfied with the implementation of ESI Act, they are highly satisfied with their jobs also. But if the level of satisfaction with the implementation of the act is low, the job satisfaction also tends to be low. Thus the proper implementation of ESI act has a strong impact on the level of job satisfaction.

\section{FINDINGS AND SUGGESTIONS}

- It is found that majority of respondents are aware of medical, sickness and maternity benefits provided under the ESI but are less aware of dependents and funeral benefits.

- The workers are not even aware of the either their rate of monthly contribution or rate of management's contribution towards the ESI. The reason being the illiteracy on the part of the workers and lack of proper awareness training modules for statutory welfare measures on the part of employers.

- Majority of the respondents have average level of satisfaction with .implementation of ESI welfare provisions. They think that ESI Scheme has provided security to the workers but it is difficult to claim benefits for them from ESI. So improvements are desirable in the scheme by improving medical service and by simplifying the procedure of getting benefits.

- Female workers are equally aware of welfare facilities provided under ESI Act. It is proved with the help of chisquare test there is a no significant relationship between the sex of the respondents and the level of awareness for welfare measures.

- Most of the workers are satisfied with the facilities in labour colony. While $17 \%$ are dissatisfied with the facilities in labour colony and they want improvement in the same in terms of timely repair of the houses.

- Most of the workers are highly benefited with the welfare measures provided by the textile industry .The proper implementation of ESI act has a strong impact on the level of job satisfaction. if the workers are highly satisfied with the implementation of ESI Act, they are highly satisfied with their jobs also

- Management can think of formulation of a problem solving committee for the better solution of the welfare problems of the workers. This committee can conduct hearings from the workers or they can conduct surprise visits to the different work spot, etc for understanding and by that solving the problems also

\section{CONCLUSION}

The main objective of this paper is to determine the awareness and satisfactory level of welfare facilities in textile industries. This paper has also attempted to study relationship between the sex of the respondents and satisfaction level for welfare measures. The outcome of the study may help the organization to differentiate the satisfying factors from dissatisfying ones and to take effective steps to improve the labour welfare facilities which in turn will increase the workers efficiency and productivity.

\section{REFRENCES}

[1] Aggarwal, A.P., Gueraoes and Industrial relations ; N.M.Tripathi, Bombay; 1968.

[2] Ahluwalia G.S., Philosophies of labour welfare; Indian Journal of social work; vol. 14; No. 1; 1953.

[3] Bhatnagar, Deepti., State and Labour welfare in India; Deep and Deep Publications, New Delhi; 1985

[4] Chopra, V.S., Strategies for healthy Labour Management relations; Haryana Labour Journal; vol.150, no. 3; July Sept.1984.

[5] Jacob, K.K., (2002), Industrial relations in Public Sector in Kerala. Ph.D. Thesis, University of Kerala

[6] Jain R.C., Path to Industrial peace; Indian Labour Journal ; Vol. 24; No. 2; 1983.

[7] Kirkaddy ,H.S., Labour problem in India: S. Chand \& Co. Ltd, Delhi ;1981;P.226.

[8] Kumar.P.Ashok., A Study on Labour welfare measures in Salem steel plant;Vol.2. issue:3;March 2012.

[9] Mathur, D.C., Personnel problems and labour welfare; Mittal Publications, New Delhi,1993 
[10] Mishra.S.N., Labour and Industrial Laws, Central law Publications, Allahabad;1997.

[11] Misra, K.K. "Labour Welfare in Indian Industries” Meenakshi Prakashan, Meetut,1974.

[12] Monga, M.L., Implementation of labour laws in Haryana; Punjabi University, Patiala, 1980; P. 56.

[13] Moorthy, M.V., Labour Welfare, Indian Journal of Social Work; Vol.11; No. 3; 1950.

[14] Personnel Management and Industrial Relations - Tripathi ; Bombay, 19th edition, reprint 2008

[15] Report of National Commission on Labour, Government of India, 2002

[16] ShobnaMishra \&Dr. Manju Bhagat2010), Principles for successful implementation of labour welfare activities from police theory to functional theory $\quad$ Retrieved June 10, 2010, from http://www.tesionline.com/int//indepthjsp

[17] Sharma, A.M.,Industrial relations, Himalaya Publishing House;New Delhi,2007.

[18] Singh, A.P. and Srivastava , A.K., Occupational Level and Job Satisfaction ; Journal of Public relations ; 19 (2) ; May 1975.

[19] Saiyadin S.Mirza, "Voluntary Welfare in India", Lok Udyog October, 1983, PP.29-33.

[20] Vaid, K.N., Labour Welfare in India, Shri Ram Centre for Industrial relations, New Delhi ; 1970.

[21] V. Pylee and A. Simon George, Industrial Relations \& Personnel Management, Vikas Publishing House Pvt. Ltd, New Delhi; 1996, p-78.

[22] Zaheeruddin., labour Welfare and Employment conditions in India; Deep and Deep Publications, New Delhi ; 1985. 